\title{
Effect of mannan oligosaccharide supplementation on blood and intestinal immune cells, bacteria numbers and performance in weaned pigs
}

\author{
Hrvoje Valpotić ${ }^{1}$, Marko Samardžija ${ }^{1}$, Svjetlana Terzić ${ }^{2}$, Silvijo Vince ${ }^{1}$, Marcela \\ $\breve{S ̌ p e r a n d a}^{3}$, Gordana Lacković ${ }^{4}$, Boris Habrun ${ }^{2}$, Nora Mas ${ }^{1}$, Dražen Đuričićc ${ }^{5}$, Predrag \\ Kočila $^{6}$, Franjo Marković ${ }^{7}$, Ivica Valpotić ${ }^{1}$ \\ ${ }^{1}$ University of Zagreb, Veterinary Faculty, Clinic for Obstetrics and Reproduction, Zagreb, Croatia \\ ${ }^{2}$ Croatian Veterinary Institute, Zagreb, Croatia \\ ${ }^{3}$ University of Osijek, Faculty of Agriculture, Osijek, Croatia \\ ${ }^{4}$ University of Zagreb, Faculty of Science, Division of Biology, Zagreb, Croatia \\ ${ }^{5}$ Veterinary Practice, Đurđevac, Croatia \\ ${ }^{6}$ Animal Feed Factory, Čakovec, Croatia \\ ${ }^{7}$ Belupo d.d. Koprivnica, Croatia \\ Received January 14, 2016 \\ Accepted August 31, 2016
}

\begin{abstract}
In animal production, alternative strategies to the use of antibiotic growth promoters have stimulated research of dietary supplements to increase resistance, reduce post-weaning gut disorders and growth checks in pigs. This study was performed to determine the influence of dietary mannan oligosaccharide as a potential alternative to antibiotic growth promoters in weaned pigs on: (1) proliferation of circulating and intestinal immune cell subsets, (2) incidence and severity of diarrhoea, and (3) performance during 35 days of trial. Forty-six pigs from a commercial farm were divided into two groups comprising 23 pigs each and treated at 4 weeks of age as follows: controls received standard weaner diet, whereas diet for principals was supplemented with $0.2 \%$ of mannan oligosaccharide. The pigs were monitored/sampled on daily, weekly or monthly basis for feed efficiency, growth rate, diarrhoea severity scores, blood samples, rectal swabs and intesinal samples for bacterial isolation/counts and immunohistology/ histomorphometry analyses. The principals were heavier $(P<0.05)$ at 28 days and grew faster between days 7 and 28 compared to controls. Total diarrhoea score recorded in these pigs was decreased by $20.37 \%$. Total bacterial load in jejunum was decreased in these pigs $\left(23 \times 10^{7}\right.$ vs. $19 \times 10^{8}$ colony forming units $\left./ \mathrm{ml}\right)$ at day 35 . Between days 28 and 35 or days 21 and 28 , the principals increased in proportions of circulating $\mathrm{CD} 45^{+}, \mathrm{CD} 4^{+}, \mathrm{CD} 21^{+}, \mathrm{CD} 8^{+}$ cells $(P<0.01)$, respectively. These pigs had increased $(P<0.05)$ the number of CD45RA ${ }^{+}$ cells in interfollicular and follicular areas of ileal Payer's patches at day 35 . We concluded that dietary modulation with mannan oligosaccharide resulted in stimulation of immune responses and reduced number of gut microbiota, but not necessarily promoting the growth of pigs.
\end{abstract}

Immunity, gut microbiota, growth, swine

The EU ban on antibiotic growth promoters (AGP) in food animal production has stimulated research for alternative strategies on weaning diets as a way of reducing postweaning gut infections and growth check as well as modulating immune functions to increase the resistance of pigs to enteric diseases. Many bioactive substances of either natural (such as the yeast derivatives glucans and mannans, herbaceous and ligneous plant extracts, seaweed extracts, animal products and by-products, i.e. colostrum, lactoferrin and spray-dried plasma) or synthetic origin (such as levamisole and polyoxyethylenepolyoxypropylene copolymer) have been investigated as alternatives to AGP but only few have been shown to be effective (Gallois et al. 2009; Valpotić et al. 2013; Valpotić et al. 2014). Among these, a variety of polysaccharides from different natural sources, such as yeast derivatives $\beta$-glucans and mannans are known to modulate the composition

Address for correspondence:

Prof. Dr. Marko Samardžija, PhD

Clinic for Obstetrics and Reproduction

Veterinary Faculty, University of Zagreb

Heinzelova 55, 10000 Zagreb, Croatia
Phone: +385-1-2390-321

Fax: +385-1-2441-390

E-mail: smarko@vef.hr

http://actavet.vfu.cz/ 
and activity of gut microbiota, stimulate immune functions and improve disease resistance (Šperanda et al. 2008; Yin et al. 2008).

Mannan oligosaccharide (MOS) can be found in large quantities in the cell wall of Saccharomyces cerevisiae, which represents the main source of feed additives currently used in pig nutrition (Kogan and Kocher 2007; Halas and Nochta 2012). As a natural nutritional supplement MOS may offer a novel approach to balance the intestinal microbiota to beneficial direction and thus may improve overall gut health and welfare (Castillo et al. 2008). Also, dietary MOS may maintain the intestinal morphology and absorptive function by increasing the villous height : crypt depth ratio of the gut in weaned pigs (Poeikhampha and Bunchaska 2011). The effect of MOS on pig performance was analysed in several meta-analyses which reported growth rate improvements in nursery rather than in fattening pigs (Miguel et al. 2004; Z ha o et al. 2012). Moreover, the addition of MOS resulted in modest growth promoting effects in healthy weaned pigs kept in high hygienic standard conditions (Miguel et al. 2004). The real growth promoting effect of MOS in weaned pigs was apparently inconsistent. Some studies reported no benefits (White et al. 2002) whereas other studies recorded an improved daily rate gain and feed efficiency in weaning pigs (Van der PeetSchwering et al. 2007; Zhao et al. 2012).

Dietary MOS has both indirect and direct modulatory effects on porcine immune response (Kim et al. 2000) by promoting bacterial antigen presentation, thereby facilitating the shift from innate to adaptive immune responses (Davis et al. 2004a). Such changes are likely attributable to an activation of the local immune defence mechanisms through the mannose binding receptors located at the apical surface of enterocytes.

More recent results suggested that MOS improved immune responses by rapidly increasing numbers of leukocytes, lymphocytes and neutrophils and growth rate of nursery pigs 7 days (d) post-infection with porcine reproductive and respiratory syndrome (PRRS) virus (Che et al. 2011a). These authors reported evidence on the potential of dietary MOS $(2 \mathrm{~g} / \mathrm{kg})$ to alleviate the hypersensitivity reaction following the PRRS-challenge infection by down-regulating the expression of non-immune and immune genes in pig leukocytes (Che et al. 2011b). In that way MOS may enhance the resistance of pigs to infection, while preventing over-stimulation of the immune system and, thus, using nutrients effectively for growth (Che et al. 2012).

Therefore, the present study was designed to assess the effects of dietary MOS supplementation as a potential alternative to AGP in weaned pigs on: (1) the proliferation rate of $\mathrm{CD} 45^{+}$lymphoid cells, $\mathrm{CD} 4^{+}$and $\mathrm{CD}^{+} \mathrm{T}$ cells, and $\mathrm{CD} 21^{+} \mathrm{B}$ cells in the peripheral blood as well as the number of CD45RA naive lymphoid cells residing their ileal mucosa, (2) the incidence and severity of diarrhoea by monitoring of changes in health status and bacterial numbers, and (3) the improvement of performance during $35 \mathrm{~d}$ of the treatment.

\section{Materials and Methods}

Animals, housing and experimental design

Forty-six crossbred pigs, both gilts and barrows, with a body weight of approximately $7.2 \pm 0.31 \mathrm{~kg}$, progeny of four litters (from $3{ }^{\text {rd }}$ parity sows) from a commercial swine farm in eastern Croatia were used. The pigs were weaned at $28 \mathrm{~d}$ of age, housed, managed and fed a standard weaner diet (without antimicrobials or growth promoters) according to the rearing technology of the farm. The weaners were randomly divided into two groups comprising 23 animals each and kept in separate pens in the same rearing facility of the farm as detailed earlier (Valpotić et al. 2014). The experiment was conducted throughout a period of $35 \mathrm{~d}$.

The animals used in this study were maintained at facilities approved by the Croatian Association for Accreditation of Laboratory Animal Care, and in accordance with current regulations and standards issued by the Ministry of Agriculture of Croatia. Experimental and animal management procedures were conducted in accordance with the "Directive for the Protection of Vertebrate Animals used for Experimental and other Purposes" (86/609/EEC). 
Experimental diets

All experimental diets were corn and soybean meal based and formulated according to the National Research Council (NRC 2001) for nutrient requirement standards for piglets (Table 1). Control pigs received standard weaner phase 1 (from day 0 to 21 ) or phase 2 (from $\mathrm{d} 22$ to 35 ) diet, whereas both diets for the experimental pigs were supplemented with $0.2 \%$ of $\operatorname{MOS}\left(\mathrm{Bio}_{-\mathrm{Mos}^{\circledR}}\right.$, Alltech, Nicholasville, KY, USA). In order to determine the kinetic of growth, feed intake, and feed conversion in the experimental pigs, we analysed the average daily gain (ADG), average daily feed intake (ADFI), and feed conversion ratio (FCR) during the experimental period of 5 weeks following weaning.

Table 1. Ingredients and chemical composition of experimental diets

\begin{tabular}{|c|c|c|}
\hline \multirow[t]{2}{*}{ Item } & \multicolumn{2}{|c|}{ Diet } \\
\hline & Phase 1 & Phase 2 \\
\hline \multicolumn{3}{|l|}{ Ingredients, $\%$ air-dry diet } \\
\hline Maize & 44.88 & 45.85 \\
\hline Barley & 11 & 14 \\
\hline Soybean meal ( $44 \%$ crude protein) & 11 & 11 \\
\hline Fish meal & 4 & 3.5 \\
\hline Dried skim milk & 12 & 4 \\
\hline Soybean, full fat & 14.5 & 15.95 \\
\hline Monocalcium phosphate & 0.8 & 0.9 \\
\hline Limestone & 0.8 & 0.9 \\
\hline Salt & 0.3 & 0.3 \\
\hline Vitamin and mineral mix* & 0.5 & 0.5 \\
\hline Lysine & 0.12 & 0.1 \\
\hline Methionine + cysteine & 0.1 & 0 \\
\hline Calculated analysis, $\%$ air-dry diet & 100 & 100 \\
\hline Crude protein & 21.61 & 19.78 \\
\hline Metabolic energy $(\mathrm{MJ} / \mathrm{kg})$ & 13.84 & 13.74 \\
\hline Lysine (g/kg) & 13.7 & 11.6 \\
\hline Methionine + cysteine $(\mathrm{g} / \mathrm{kg})$ & 8.3 & $6.7^{*}$ \\
\hline
\end{tabular}

*Provided the following amounts of minerals and vitamins per kilogram of diet: $18 \mathrm{mg} \mathrm{Cu,} 110 \mathrm{mg} \mathrm{Zn}$, $0.2 \mathrm{mg} \mathrm{I}, 110 \mathrm{mg} \mathrm{Fe}, 50 \mathrm{mg} \mathrm{Mn}, 0.3 \mathrm{mg} \mathrm{Se}, 20000 \mathrm{IU}$ of vitamin A; $3200 \mathrm{IU}$ of vitamin D; $120000 \mathrm{IU}$ of vitamin E; $7000 \mathrm{mg}$ of vitamin $\mathrm{K} ; 70 \mathrm{mg}$ of vitamin $\mathrm{B}_{12} ; 200 \mathrm{mg}$ of folic acid; $120000 \mathrm{mg}$ of pantothenic acid; $4000 \mathrm{mg}$ of pyridoxine; $16000 \mathrm{mg}$ of riboflavin; $3000 \mathrm{mg}$ of thiamin

\section{Data and sample collection}

The pigs were monitored daily and sampled (for samples of peripheral blood and rectal swabs) at 7-d intervals starting at $\mathrm{d} 0$ before the treatment. At both d 0 and d 35 of the experiment, 5 pigs per group were euthanized by intracardial injection of $0.3 \mathrm{ml} / \mathrm{kg}$ of T61 preparation (Hoechst, München, Germany) and sampled for bacteriology and immunohistology. The pigs were weighed at weekly intervals during the experiment and changes in their body weight were recorded. Body weight gain was calculated as the initial and final weights of the different periods. Feed intake was recorded on weekly basis, and efficiency of feed utilization was calculated by dividing the feed intake and body weight gain.

\section{Health status and diarrhoea scoring}

The pigs were monitored daily for diarrhoea and other clinical signs of gut health disorders such as anorexia and weight loss. The severity of diarrhoea was quantified by using the faecal consistency scoring method of Marquardt et al. (1999) as described previously (Valpotić et al. 2014).

\section{Sampling for the analyses of intestinal microbiota}

For the monitoring of bacterial numbers we determined bacterial species and serovars isolated from rectal swabs and jejunal contents. The rectal swabs were taken from 5 pigs per group at d $0,14,21$ and 35 of the experiment for isolation and serotyping of the enteric bacteria. Immediately following euthanasia of 5 pigs per 
group both at $\mathrm{d} 0$ and $\mathrm{d} 35$, respectively, a $10 \mathrm{~cm}$ segment of mid jejunum with the digestive content was ligated and taken for the counting of intraluminal bacteria.

\section{Bacteriology}

For determination of the total number of $E$. coli cells in $1 \mathrm{ml}$ of the jejunal content (colony forming units; $\mathrm{CFU} / \mathrm{ml}$ ) the samples were diluted in serial dilutions up to $10^{10}$ in saline and each dilution was placed onto selected culturing plates (International Organization for Standardization-ISO 16649-2:2001) (Winn et al. 2006) as described earlier by Valpotić et al. (2014). The identification and serotyping of isolates for fimbrial antigens of E. coli F4, F5, F6 and F18 were performed as previously detailed (Valpotić et al. 2014).

\section{Analysis of peripheral blood immune cell subsets by flow cytometry (FCM)}

Blood samples $(1 \mathrm{ml})$ from 7 pigs in each group were taken weekly from vena cava cranialis into glass tubes (Beckton Dickinson, Plymouth, UK) with ethylenediaminetetraacetic acid (EDTA) (Sigma, Germany) as anticoagulant for FCM analysis as described previously (Valpotić et al. 1994; Božić et al. 2002).

Immunohistological and histomorphometric analyses of intestinal immune cells

Immediately following euthanasia at both $\mathrm{d} 0$ and $\mathrm{d} 35$, five specimens of mid ileum (both 5-6 and 7-8 cm proximal to the ileocaecal junction), were fixed in 10\% neutral-buffered formalin ( $\mathrm{pH} 7.0-7.6)$ for $24 \mathrm{~h}$ until used for immunohistology analyses. The paraplast-embedded sections were processed for an indirect immunoperoxidase (IP) method using primary and secondary Abs as detailed earlier (Lacković et al. 1997; Valpotić et al. 2014). Histomorphometric analysis of CD45RA ${ }^{+}$lymphoid cells within compartments of ileal mucosa was performed using commercial software imaging program Lucia G (version 4.11) for digital image analysis (DIA) as described before (Kovšca-Janjatović et al. 2009; Valpotić et al. 2014).

\section{Statistical analyses}

Numerical data were analysed by Student's $t$-test for dependent samples using the Statistica SixSigma software (StatSoft, Inc.). The generalized linear mixed model (PROC GLIMMIX) in SAS 9.3 (2002-2010 SAS Institute Inc., Cary, NC, USA) was used to analyse the obtained data. The statistical model included the fixed effects of group, day and their interactions. The animal effects on repeated measures over time included in the model by RANDOM statement with RESIDUAL option and compound-symmetry structure. Multiple comparison test of the least-square means with Bonferroni correction was performed using SLICE option to compare each level of group within each level of time. Significance of differences between the treated and control groups of pigs was considered at $P<0.05$.

\section{Production indicators}

\section{Results}

Pigs fed a diet supplemented with MOS showed a significantly increased body weight at $\mathrm{d} 28(P<0.05)$ of the experiment compared to the control pigs (Table 2$)$. The pigs treated with MOS had an increased ADG between d 7 and d 28 of the experiment, with the exception of the periods of $\mathrm{d} 0-7$, and $\mathrm{d} 28-35$, when the control pigs showed either a slightly $(214 \mathrm{~g}$ vs. $203 \mathrm{~g})$ or a significantly increased $(P<0.05)$ growth rate, respectively (Table 3). During the experimental period, the ADG increased in the control pigs $(296 \mathrm{~g}$ vs. $268 \mathrm{~g}$ ). Also, the control pigs had an increased ADFI during most of the experimental

Table 2. Body weight (BW) changes in weaned pigs fed diet supplemented with mannan oligosaccharide (MOS).

\begin{tabular}{|c|c|c|c|c|}
\hline \multirow{2}{*}{ Day } & \multicolumn{2}{|c|}{ Mean BW (kg) } & \multirow{2}{*}{ SEM } & \multirow{2}{*}{$P$ - value } \\
\hline & None $^{*}$ & $\mathrm{MOS}^{\dagger}$ & & \\
\hline 0 & 7.18 & 7.32 & 0.32 & 0.761 \\
\hline 7 & 8.91 & 8.83 & 0.32 & 0.866 \\
\hline 14 & 10.05 & 9.78 & 0.31 & 0.545 \\
\hline 21 & 12.03 & 11.83 & 0.33 & 0.672 \\
\hline 28 & 13.10 & $14.20^{\mathrm{a}}$ & 0.34 & 0.025 \\
\hline 35 & 17.21 & 17.45 & 0.37 & 0.643 \\
\hline
\end{tabular}

*Standard weaner diet only or ${ }^{\dagger}$ diet supplemented with $0.2 \%$ MOS; groups comprised 23 pigs each at d 0 of experiment. ${ }^{a}$ Values differ significantly at $P<0.05$.

$\mathrm{SEM}=$ standard error of the mean 
Table 3. Performance of weaned pigs during 35 days of the experiment.

\begin{tabular}{lcccccc}
\hline Treatment* & 7 & 14 & 21 & 28 & 35 & $0-35$ \\
\hline None & & & & & & \\
Average daily gain & 214 & 172 & 273 & 261 & 562 & 296 \\
Average daily feed intake & 419 & 464 & 780 & 565 & 975 & 641 \\
Feed conversion rate & 1.96 & 2.70 & 2.86 & 2.16 & 1.74 & 2.17 \\
\hline Mannan oligosaccharide (MOS) & & & & & & \\
Average daily gain & 203 & 185 & 343 & 333 & 277 & 268 \\
Average daily feed intake & 334 & 383 & 549 & 707 & 721 & 539 \\
Feed conversion rate & 1.65 & 2.07 & 1.60 & 2.12 & 2.60 & 2.01 \\
\hline
\end{tabular}

*Standard weaner diet only or ${ }^{\dagger}$ diet supplemented with $0.2 \%$ MOS; groups comprised 23 pigs each at d 0 of experiment.

Table 4. Incidence and severity of diarrhoea in weaned pigs fed diet supplemented with mannan oligosaccharide (MOS).

\begin{tabular}{lccc}
\hline \multirow{2}{*}{ Treatment* $^{*}$} & No. of diarrhoeic pigs & & \multicolumn{2}{c}{ Diarrhoea severity score (DSS) } \\
\cline { 3 - 4 } & & Sum of DSS & \% difference \\
\hline None & $12 / 23(52.17 \%)$ & 54 & $/$ \\
MOS & $6 / 23(26.09 \%)$ & 43 & -20.37 \\
\hline
\end{tabular}

*Standard weaner diet only or diet supplemented with $0.2 \%$ of MOS; ${ }^{\dagger}$ during $35 \mathrm{~d}$ of experiment; ${ }^{\S} \mathrm{DSS}$ : $0=$ normal faeces, $1=$ soft faeces; 2 = fluid faeces or $3=$ severe diarrhoea

period, except between d 21 and d 28 (707g vs. $565 \mathrm{~g}$ ). These pigs had a considerably increased ADFI (641 g vs. $539 \mathrm{~g}$ ) during $35 \mathrm{~d}$ of the experiment. However, the pigs fed a diet supplemented with MOS had a decreased FCR (2.01 vs. 2.17) compared to control pigs.

\section{Clinical and bacteriological indicators}

The sum of DSS observed in the pigs that received MOS supplementation was decreased by $20.37 \%$ (43 vs. 54) compared to the controls (Table 4). Numbers of haemolytic/ nonhaemolytic $E$. coli isolates were slightly increased in the experimental group compared to control (7 vs. 6) during the $35 \mathrm{~d}$ of experiment. A total bacterial load in the jejunum was decreased in MOS supplemented pigs $\left(23 \times 10^{7}\right.$ vs. $\left.19 \times 10^{8} \mathrm{CFU} / \mathrm{ml}\right)$ at the end of the experiment (Table 5).

Expression of systemic and intestinal immune cell subsets

Proportions of lymphoid cell subsets tested, with the exception of $\mathrm{CD} 8^{+} \mathrm{T}$ cells, were significantly increased in the MOS-supplemented pigs than those in the control pigs during the last two weeks of the experiment (Table 6). At d 21 we recorded significantly increased proportions of $\mathrm{CD}_{4} 5^{+}, \mathrm{CD}^{+}, \mathrm{CD} 21^{+}$cells $(P<0.01)$. Proportions of $\mathrm{CD} 45^{+}$, $\mathrm{CD}^{+}$and $\mathrm{CD}^{+}$cells were significantly decreased in the experimental pigs before MOS supplementation starting from d $0(P<0.01)$ compared to the controls (Table 6). Although decreased at $\mathrm{d} 0$ in the MOS group (20.10\% vs. $22.10 \%)$, the proportion of CD21 $1^{+} \mathrm{B}$ cells was not significantly different than that found in the control pigs (Table 6). Distribution patterns and frequency of CD45RA ${ }^{+}$cells within interfollicular (IFA) and follicular areas (FA) of the ileal Payer's patches (PP) from the pigs fed diet supplemented with MOS at 
Table 5. Bacterial isolates from rectal swabs of weaned pigs fed diet supplemented with mannan oligosaccharide (MOS) and number of bacteria (colony forming units; $\mathrm{CFU} / \mathrm{ml}$ ) in the jejunal content from 5 pigs per group euthanized at $\mathrm{d} 0$ or $\mathrm{d} 35$, respectively.

\begin{tabular}{|c|c|c|c|c|c|}
\hline \multirow{2}{*}{ Treatment* } & \multirow{2}{*}{ t* Indicator } & \multicolumn{4}{|c|}{ Day } \\
\hline & & 0 & 14 & 21 & 35 \\
\hline \multirow[t]{5}{*}{ None } & \multirow{4}{*}{$\begin{array}{l}\text { Bacterial } \\
\text { isolates }^{\dagger}\end{array}$} & Enterococcus faecium $(+)$, & E. coli $($ Hly $)(+)$, & E. coli $($ nHyi) $(++)$, & E. spp. $(++)$ \\
\hline & & Proteus spp. (+) & E. coli (nHly) & E. coli $(H l y)(+++)$ & E. coli $($ nHly $)(+)$, \\
\hline & & E. coli $(\mathrm{Hly})(++)$, & and $E$. spp. $(+)$ & E. coli (nHly) & \\
\hline & & E. coli (nHly) $(+)$ & E. coli $(\mathrm{nHly})(++), \mathrm{NF}(+)$ & and $E$. spp. $(++)$ & \\
\hline & $\begin{array}{l}\text { No. of bacteria } \\
(\mathrm{CFU} / \mathrm{ml})\end{array}$ & $90 \times 10^{8}$ & l & l & $19 \times 10^{8}$ \\
\hline \multirow{6}{*}{ MOS } & \multirow{5}{*}{$\begin{array}{l}\text { Bacterial } \\
\text { isolates }^{\dagger}\end{array}$} & \multicolumn{4}{|c|}{ E. coli $(\mathrm{nHly})(+)}$, \\
\hline & & E. coli $(\mathrm{Hly})(+)$, & E. coli (Hly) & E. coli $($ Hly $)(+)$, & E. coli $($ nHly $)(+)$, \\
\hline & & E. coli $(\mathrm{nHly})(+++)$ & and E. spp. $(+++)$, & E. coli 0149:K91:F4 (Hly) (+), & E. coli (nHly) \\
\hline & & E. coli $0149: \mathrm{K} 91: \mathrm{F} 4$ & E. spp. $(+)$, & E. coli (Hly) & and $E$. spp. $(+++)$, \\
\hline & & (Hly) $(+)$ & E. faecium $(+)$ & and $E$. spp. $(+)$ & E. spp. $(+)$ \\
\hline & $\begin{array}{l}\text { No. of } \\
\text { bacteria }^{\S} \\
(\mathrm{CFU} / \mathrm{ml})\end{array}$ & $48 \times 10^{7}$ & I & l & $23 \times 10^{7}$ \\
\hline
\end{tabular}

*Standard weaner diet only or the diet supplemented with $0.2 \% \mathrm{MOS}$; groups comprised 5 pigs each at d 0 of experiment; ${ }^{\dagger}$ species/ serovar of isolates $=$ no of positive $(+)$ or negative $(-)$ findings $(\mathrm{NF})$ per pig; Hly $=$ haemolytic or nHly $=$ nonhaemolytic; ${ }^{\S}$ no. of bacteria in the content of $10 \mathrm{~cm}$ segment of mid jejunum from 5 pigs per group euthanatized at $\mathrm{d} 0$ or $\mathrm{d} 35$, respectively.

Table 6. Difference in proportion of lymphoid cell subsets in the peripheral blood of weaned pigs fed diet supplemented with mannan oligosaccharide (MOS).

\begin{tabular}{llllllll}
\hline Treatment* & 0 & 7 & 14 & 21 & 28 & 35 & SEM \\
\hline $\begin{array}{l}\text { Control } \\
\text { CD } 45^{+}\end{array}$ & $55.31^{\mathrm{a}}$ & 56.30 & 58.30 & 61.0 & 61.30 & 62.0 & 0.79 \\
$\mathrm{CD}^{+}$ & $19.34^{\mathrm{a}}$ & 20.0 & 21.0 & 21.20 & 22.0 & 22.0 & 0.28 \\
$\mathrm{CD}^{+}$ & $11.10^{\mathrm{a}}$ & 11.14 & 12.0 & 12.10 & 12.30 & 12.34 & 0.16 \\
$\mathrm{CD} 21^{+}$ & 22.10 & 22.11 & 23.20 & 24.40 & 25.0 & 25.0 & 0.34 \\
\hline $\mathrm{MOS}$ & & & & & & \\
$\mathrm{CD} 45^{+}$ & 50.6 & 54.0 & 60.0 & $66.0^{\mathrm{a}}$ & $69.50^{\mathrm{a}}$ & $69.70^{\mathrm{a}}$ & 0.61 \\
$\mathrm{CD} 4^{+}$ & 18.0 & 19.0 & 21.0 & 23.02 & $24.30^{\mathrm{a}}$ & $24.30^{\mathrm{a}}$ & 0.21 \\
$\mathrm{CD} 8^{+}$ & 10.11 & 11.0 & 12.0 & $13.20^{\mathrm{a}}$ & $14.0^{\mathrm{a}}$ & 14.0 & 0.13 \\
$\mathrm{CD} 21^{+}$ & 20.10 & 21.60 & 24.0 & $26.33^{\mathrm{a}}$ & $27.80^{\mathrm{a}}$ & $27.74^{\mathrm{a}}$ & 0.23 \\
\hline
\end{tabular}

*Standard weaner diet only or the diet supplemented with $0.2 \%$ MOS; groups comprised 7 pigs each at d 0 ; a Values differ significantly at $P<0.01$ from those in the non-treated controls.

$\mathrm{SEM}=$ standard error of the mean

d 35 of the experiment are shown in Plate VII, Fig. 1 and 2 (a,b), respectively. Numerous $\mathrm{CD}_{45 \mathrm{RA}^{+}}$naive lymphoid cells were visible in the ileal lamina propria of the intestinal villi, within Lieberkühn's crypts and in the submucosa. These cells were rarely found adjacent to the basal membrane of enterocytes, but were densely distributed in the middle of villous lamina propria and in the IFA (Fig. $1 \mathrm{a}, \mathrm{b}$ ). An increase in the frequency of CD45RA ${ }^{+}$cells was observed in the FA of the ileal PP (Fig. 2 a,b). Microscopic examination showed an 
increase in the recruitment of CD45RA ${ }^{+}$cells residing in both compartments of the ileal $\mathrm{PP}$ in pigs fed diet supplemented with MOS (Table 7). Such examination was confirmed numerically by DIA, within IFA (30.41 vs. 15.60) rather than FA (637.40 vs. 504.80) of the ileal PP of pigs following $35 \mathrm{~d}$ of the treatment. By microscopic examination it was observed that CD45RA ${ }^{+}$naive lymphoid cells were less numerous within both IFA and FA at $\mathrm{d} 0$ compared to $\mathrm{d} 35$. This observation was confirmed by DIA as the numbers of these cells residing in IFA (4.83) and FA (1.97) before the treatment at $\mathrm{d} 0$ were significantly $(P<0.001)$ decreased than those within these compartments at $\mathrm{d} 35$ of the experiment $(15.60 \pm 1.70$ or $504.80 \pm 25.60$, respectively; Table 7$)$.

Table 7. Numbers of CD45RA ${ }^{+}$naive lymphoid cells in intrafollicular areas (IFA) and follicular areas (FA) of the ileal Payer's patches (PP) of weaned pigs supplemented with mannan oligosaccharide (MOS) from day 0 during 35 days of the experiment.

\begin{tabular}{lccc}
\hline Treatment* & None & MOS & SEM \\
\hline FA & 504.80 & $637.40^{\mathrm{a}}$ & 35.01 \\
IFA & 15.60 & $30.41^{\mathrm{a}}$ & 1.3 \\
\hline
\end{tabular}

*Standard weaner diet only or the diet supplemented with $0.2 \%$ MOS; 5 pigs per group were euthanized and sampled at both d 0 (data not shown) and d 35, respectively; ${ }^{a}$ Values differ significantly at $P<0.05$ from that in the non-treated controls. SEM = standard error of the mean

\section{Discussion}

The influence of dietary MOS on growth performance, with the exception of increased body weight in the MOS-treated pigs at d 28 of the experiment, was in agreement with findings of those authors who reported that the supplement did not promote growth and feed efficiency in weaned pigs (White et al. 2002; Wenner et al. 2013), but contrasted with the authors who observed improved average daily gain in pigs fed diets with yeast culture, including cell wall mannans (Van der Peet-Schwering et al. 2007) or MOS (Che et al. 2011a). The results obtained in the current study showed an immunostimulating instead of a growth promoting effect of MOS in weaned pigs. This effect could be explained by the fact that overstimulation of the immune system can divert nutrients from growth towards supporting defence mechanisms (Che et al. 2011a; Che et al. 2012).

The immunomodulation effects of mannans are still controversial, particularly regarding their influence on local cellular immunity within the gut-associated lymphoid tissues (GALT). At the level of intestinal lamina propria, macrophage phagocytosis seems to be enhanced by dietary mannans (Davis et al. 2004b). However, the recruitment of lymphocytes within the small intestinal lamina propria was reduced in pigs fed mannans (Lizardo et al. 2008) and the ratio of $\mathrm{CD}^{+} / \mathrm{CD}^{+} \mathrm{T}$ cells was decreased $21 \mathrm{~d}$ post weaning, indicating a greater proportion of $\mathrm{CD}^{+} \mathrm{T}$ cells in mannan-supplemented pigs (Davis et al. 2004b). The former observation was not in agreement with our finding that the pigs fed MOS had significantly increased number of CD45RA ${ }^{+}$cells after $35 \mathrm{~d}$ of the experiment in both IFA and FA of the ileal PP, well known to be predominantly populated by either $\mathrm{T}$ or B cells, respectively. Literature dealing with the effect of MOS on the recruitment of porcine immune cells within the GALT is very scarce (Davis et al. 2004; Sauerwein et al. 2007; Lizardo et al. 2008), and to our knowledge, is completely missing regarding PP. Thus, we can only mention our recent finding that weaned pigs fed zeolite clinoptilolite supplement showed an increased number of CD45RA+ cells in the IFA of the ileal PP at d 35 of the experiment (Valpotić et al. 2016), which partly agrees with the results obtained in the present study. However, the later finding complementarily supports those of the 
abovementioned authors, indicating that further research is needed to define the potential of dietary MOS to non-selectively stimulate porcine T and B cells.

Systemic immune response to dietary mannans has been more widely studied, but obtained data are inconsistent. The proportions of peripheral blood $\mathrm{CD}^{+}$or $\mathrm{CD}^{+} \mathrm{T}$ cells were unchanged following mannan supplementation in early weaned pigs (Kim et al. 2000). However, Davis et al. (2004b) found a decreased blood neutrophils : lymphocytes ratio in pigs fed with $0.3 \%$ of phosphorylated mannans, suggesting that dietary mannans could moderate the inflammatory response associated with the stress accompanying weaning. These authors assumed that the proliferative response of peripheral blood lymphocytes was not affected by dietary mannans in nursery pigs (Davis et al. 2004a; Davis et al. 2004b). Although when they were continuously fed MOS at a dose rate of $0.3 \%$ the ability of lymphocytes to proliferate after stimulation with common mitogens was reduced (Davis et al. 2004a). They suggested that this altered cellular immune function may explain beneficial effects of mannans for pig growth, but there were no data from their studies concerning morbidity and mortality to assess the health effects of such immune depression. Generally, the former studies are contrasting to our findings of significantly increased recruitment rate of all cell subsets tested during the last two weeks (from d 28 to $\mathrm{d} 35$ ) of the experiment $\left(\mathrm{CD} 45^{+}, \mathrm{CD}^{+}, \mathrm{CD} 21^{+}\right.$cells) and one week earlier, i.e. from d 21 to $\mathrm{d} 28$ (CD8 ${ }^{+}$cells) in the MOS-treated pigs. However, the increased blood $\mathrm{B}$ and $\mathrm{T}$ lymphocyte populations among leukocytes in the pigs fed $0.16 \%$ of MOS originated from the brewer's yeast (White et al. 2002) were consistent with our findings, indicating that the influence of mannans on porcine immunity could be reliable. The latter study and the data of the current study were supported with the recent observation that the pigs fed $0.2 \%$ of MOS from baker's yeast had increased blood leukocytes at the early stage of the experimental infection with PRRS (Che et al. 2011a).

Our observation that the sum of DSS in the MOS-treated pigs was decreased by $20.37 \%$, could be ascribed to its prebiotic activity to "adsorb" enteric pathogens rather than to eubiosis as suggested earlier (Firon et al. 1987). In the current study, the numbers of haemolytic $E$. coli isolates were slightly increased in the MOS-treated than in the control pigs (7 vs. 6), but a total bacterial load in the jejunum was decreased in the pigs treated with $\operatorname{MOS}\left(23 \times 10^{7}\right.$ vs. $\left.19 \times 10^{8} \mathrm{CFU} / \mathrm{ml}\right)$. The latter results on CFU numbers agreed well with those studies suggesting that dietary MOS supplementation can reduce the number of harmful bacteria in the gut of pigs exposed to infection (White et al. 2002; Liu et al. 2008). It is likely that all three mechanisms proposed by Kogan and Kocher (2007) contributed to the antimicrobial effect of dietary MOS observed in our study. However, we assumed that the immunostimulatory effect of MOS on gut immunity, i.e. proliferation of $\mathrm{CD}_{45 \mathrm{RA}^{+}}$lymphoid cells in the inductive sites such as the ileal PP established a protective immune response which resulted in a decreased intestinal bacterial load.

The ability of dietary MOS to stimulate both systemic and mucosal immunity and to modulate intestinal microbiota in weaned pigs suggested the use of this feed additive in intensive pig production. Considering all of the above, it can be concluded that MOS has shown to be effective as an immunostimulating agent for the recruitment of circulating and intestinal immune cell subsets, and thus, could be of importance in establishing the resistance of weaned pigs to enteric infections, resulting in the reduction of postweaning diarrhoeal disease. However, there are still some unsolved issues to be addressed considering possible overstimulation of the immune system that could be detrimental to growth promotion.

\section{Acknowledgements}

The current study was supported by the grants 053-0532265-2255 and 079-0793448-3438 from the Ministry of Science, Education and Sport of Croatia. The authors declare that they have no conflict of interest. 


\section{References}

Božić F, Lacković G, Stokes CR, Valpotić I 2002: Recruitment of intestinal CD45RA ${ }^{+}$and CD45RC ${ }^{+}$cells induced by a candidate oral vaccine against porcine post-weaning colibacillosis. Vet Immunol Immunopathol 86: $137-146$

Castillo M, Martin-Orue SM, Taylor-Pickard JA, Perez JF, Gasa J 2008: Use of mannan-oligosaccharides and zinc chelate as growth promoters and diarrhea preventative in weaning pigs: Effects on microbiota and gut function. J Anim Sci 86: 94-101

Che TM, Johnson RW, Kelley KW, Dawson KA, Moran CA and Pettigrew JE 2012: Effects of mannan oligosaccharide on cytokine secretion by porcine alveolar macrophages and serum cytokine concentrations in nursery pigs. J Anim Sci 90: 657-668

Che TM, Johnson RW, Kelley KW, Van Alstine WG, Dawson KA, Moran CA, Pettigrew JE 2011a: Mannan oligosaccharide improves immune responses and growth efficiency of nursery pigs experimentally infected with porcine reproductive and respiratory syndrome virus. J Anim Sci 89: 2592-2602

Che TM, Johnson RW, Kelley KW, Van Alstine WG, Dawson KA, Moran CA, Pettigrew JE 2011b: Mannan oligosaccharide modulates gene expression profile in experimentally infected with porcine reproductive and respiratory syndrome virus. J Anim Sci 89: 3016-3029

Davis ME, Brown DC, Maxwell CV, Johnson ZB, Kegley EB, Dvorak RA 2004a: Effect of phosphorylated mannans and pharmacological additions of zinc oxide on growth and immunocompetence of weanling pigs. J Anim Sci 82: 581-587

Davis ME, Maxwell CV, Erf GF, Brown DC, Wistuba TJ 2004b: Dietary supplementation with phosphorylated mannans improves growth response and modulates immune function of weanling pigs. J Anim Sci 82: 1882-1891

Firon N, Ashkenazi S, Mirelman D, Ofek I, Sharon N 1987: Aromatic alpha-glycosides of mannose are powerful inhibitors of the adherence of type 1 fimbriated Escherichia coli to yeast and intestinal epithelial cells. Infect Immunol 55: 472-476

Gallois M, Rothkǒtter HJ, Bailey M, Stokes CR, Oswald IP 2009: Natural alternatives to in-feed antibiotics in pig production: can immunomodulators play a role? Animal 3: 1644-1661

Halas V, Nochta I 2012: Mannan oligosaccharides in nursery pig nutrition and their potential mode of action. Animals 2: 261-274

Kim JD, Hyun Y and Sohn K 2000: Effects of mannanoligosaccharide and protein levels on growth performance and immune status in pigs weaned at 21 days of age. J Anim Sci Technol (Korean) 42: 489-498

Kogan G, Kocher A 2007: Role of yeast cell wall polysaccharides in pig nutrition and health protection. Livestock Sci 109: 161-165

Kovšca-Janjatović A, Lacković G, Božić F, Špoljarić D, Popović M, Valpotić H, Vijtiuk N, Pavičić Ž, Valpotić I 2009: Histomorphometric characteristics of immune cells in small intestine of pigs perorally immunized with vaccine candidate F18 $\mathrm{ac}^{+}$nonenterotoxigenic $E$. coli strain. Eur J Histochem 53: 189-198

Lacković G, Vijtiuk N, Ćurić S, Dean-Nystrom EA, Casey TA, Valpotić I 1997: Detection of wCD1, SWC1a, SWC2 and CD45 molecules by immunofluorescence or immunoperoxidase techniques in porcine gutassociated lymphoid tissues following experimentally induced colibacillosis. Period Biol 99: 343-350

Liu P, Piao XS, Kim SW, Wang L, Shen YB, Lee HS, Li SY 2008: Effects of chito-oligosaccharide supplementation on the growth performance, nutrient digestability, intestinal morphology, and fecal shedding of Escherichia coli and Lactobacillus in weaning pigs. J Anim Sci 86: 2609-2618

Lizardo R, Nofrarias M, Guinvarch J, Justin AL, Auclair E, Brufau J 2008: Influence se l'incorporation de levures Saccharmyces cerevisiae ou des leurs parois dans l'aliment sur la digestion et les performances zootechniques des porcelets en post-sevrage. In 40emes Journees de la Recherche Porcine, Paris, France, pp. 183-190

Marquardt RR, Jin LZ, Kim JW, Fang L, Frohlich AA, Baidoo SK 1999: Passive protective effect of egg-yolk antibodies against enterotoxigenic Escherichia coli $\mathrm{K} 88+$ infection in neonatal and early-weaned piglets. FEMS Immunol Med Microbiol 23: 283-288

Miguel JC, Rodriguez-Zas SL, Pettigrew JE 2004: Efficacy of a mannan oligosaccharide $\left(\right.$ Bio-Mos $\left.^{\mathbb{B}}\right)$ for improving nursery pig performance. J Swine Health Prod 12: 296-307

NATIONAL RESEARCH COUNCIL 2001: Nutrient Requirements of Pigs. $7^{\text {th }}$ rev. ed. Natl. Acad. Press, Washington, DC, USA.

Poeikhampha T, Bunchaska C 2011: Effects of sodium gluconate, mannan oligosaccharide and potassium diformate on growth performance and small intestinal morphology of nursery pigs. Asian-Aust. J Anim Sci 24: $844-850$

Sauerwein H, Schmitz S, Hiss S 2007: Effects of dietary application of a yeast cell wall extract on innate and acquired immunity, on oxidative status and growth performance in weanling piglets and on the ileal epithelium in fattened pigs. J Anim Physiol Anim Nutr 91: 369-380

Šperanda M, Đidara M, Šperanda T, Domaćinović M, Valpotić H, Kovačević J, Antunović Z, Novoselec J 2008: Hydrolyzed brewery yeast product like immunomodulator in weaned piglets. Archiva Zootechnica 11: 52-60

Valpotić H, Mršić G, Gršković B, Špoljarić D, Kezić D, Srečec S, Mataušić-Pišl M, Lacković G, Capak D, Mihelić D, Vlahović, K, Valpotić I, Pirkić A, Anđelinović D, Popović M 2013: Effect of polyoxyethylene and polyoxypropylene nonionic block copolymers on performance and recruitment of immune cell subsets in weaned pigs. Acta Vet Scand 55: 54-62 
Valpotić H, Šperanda M, Kovšca-Janjatović A, Đidara M, Lacković G, Božić F, Habrun B, Srečec S, MataušićPišl M, Valpotić I 2014: Levamisole stimulates proliferation of circulating and intestinal immune cell subsets, gut health and performance in weaned pigs. Can J Anim Sci 94: 43-53

Valpotic H, Terzic S, Vince S, Samardzija M, Turk R, Lackovic G, Habrun B, Djuricic D, Sadikovic M, Valpotic I 2016: In-feed supplementation of a clinoptilolite favourably modulates intestinal and systemic immunity and some production parameters in weaned pigs. Vet Med 61: 317-327

Valpotić I, Vijtiuk N, Trutin-Ostović K, Casey TA, Dean-Nystrom EA, Lacković G 1994: Identification and distribution of $\mathrm{CD}^{+} \mathrm{T}$ cell subsets in porcine gut following experimental infection with $\mathrm{F} \mathrm{ac}^{+}$enterotoxigenic Escherichia coli (ETEC) or non-ETEC strains. Reg Immunol 6: 387-390

Van der Peet-Schwering CMC, Jansman AJM, Smidt H, Yoon I 2007: Effect of yeast culture on performance, gut integrity, and blood cell composition of weanling pigs. J Anim Sci 85: 3099-3109

Wenner BA, Zerby HN, Boler DD, Gebreyes WA, Moeller SJ 2013: Effect of mannan oligosaccharides (Bio-Mos) and outdoor access housing on pig growth, feed efficiency and carcass composition. J Anim Sci 91: 4936-4944

White LA, Newman MC, Cromwell GI, Lindemann MD 2002: Brewers dried yeast as a source of mannanoligosaccharides for weanling pigs. J Anim Sci 80: 2619-2628

Winn W, Allen S, Janda W, Koneman E, Procop G, Schreckenberger P, Woods G 2006: Koneman's color atlas and textbook of diagnostic microbiology. $6^{\text {th }}$ edn, (Winn W, Ed.) Lippincott, Williams and Wilkins, London.

Yin YL, Tang ZR, Sun ZH, Liu ZQ, Li TJ, Huang RL, Ruan Z, Deng ZY, Gao B, Chen LX, Wu CY, Kim SW 2008: Effect of galacto-mannan-oligosaccharides or chitosan supplementation on cytoimmunity and humoral immunity in early-weaned piglets. Asian-Austral J Anim Sci 21: 723-731

Zhao PY, Jung JH, Kim IH 2012: Effect of mannan oligosaccharides and fructan on growth performance, nutrient digestibility, blood profile, and diarrhea score in weaned pigs. J Anim Sci 90: 833-839 
Plate VII

Valpotić H. et al.: Effects of mannan ... pp. 267-276
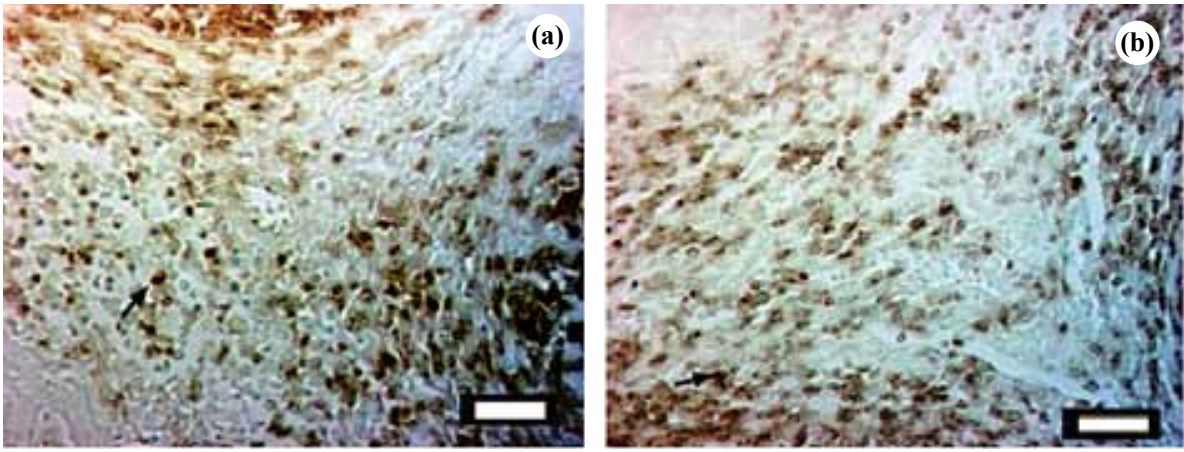

Fig. 1. CD45RA ${ }^{+}$lymphoid cells within interfollicular areas (IFA) of ileal mucosa of pig from the control group (a) and from the mannan oligosaccharide (MOS)-treated group (b) after 5 weeks of the experiment; immunoperoxidase (IP) method, scale bar $=50 \mu \mathrm{m}$.
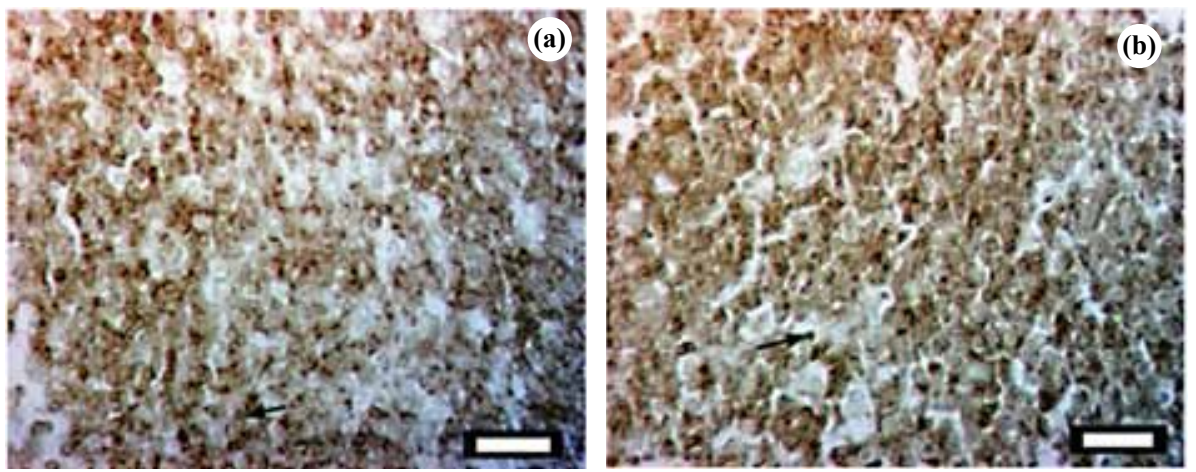

Fig. 2. CD45RA ${ }^{+}$lymphoid cells within follicular areas (FA) of ileal Payer's patches (PP) of pig from the control group (a) and from the mannan ologosacharide (MOS)-treated group (b) after 5 weeks of the experiment; immunoperoxidase (IP) method, scale bar $=50 \mu \mathrm{m}$. 